\begin{tabular}{|l|l|l||}
\hline \multicolumn{2}{|c|}{ PublisherInfo } \\
\hline \hline PublisherName & $:$ & BioMed Central \\
\hline \hline PublisherLocation & $:$ & London \\
\hline \hline PublisherImprintName & $:$ & BioMed Central \\
\hline \hline
\end{tabular}

\title{
Investigating insulin
}

\begin{tabular}{|l|l|l||}
\hline \multicolumn{2}{|c|}{ ArticleInfo } \\
\hline \hline ArticleID & $:$ & 4682 \\
\hline \hline ArticleDOI & $:$ & $10.1186 /$ gb-spotlight-20030121-01 \\
\hline \hline ArticleCitationID & $:$ & spotlight-20030121-01 \\
\hline \hline ArticleSequenceNumber & $:$ & 34 \\
\hline \hline ArticleCategory & $:$ & Research news \\
\hline ArticleFirstPage & $:$ & 1 \\
\hline \hline ArticleLastPage & $:$ & 2 \\
\hline \hline & & RegistrationDate : 2003-1-21 \\
ArticleHistory & $:$ & OnlineDate \\
\hline \hline ArticleCopyright & $:$ & BioMed Central Ltd2003-1-21 \\
\hline \hline ArticleGrants & $:$ & \\
\hline \hline ArticleContext & $:$ & 130594411 \\
\hline \hline
\end{tabular}




\section{Jonathan B Weitzman}

Email: jonathanweitzman@hotmail.com

Previous studies showed that adult or embryonic stem (ES) cells can differentiate in vitro to form insulin-containing, islet-like structures. In the January 17 Science Rajagopal et al. add a note of caution to the interpretation of such insulin-staining experiments (Science 2003, 299:363). ES cells could differentiate into clusters of cells that are recognized by an antibody against insulin, but Rajagopal et al. were alarmed that they could not detect any insulin mRNA. Furthermore, ES cells expressing green fluorescence protein from an insulin promoter did not glow green. Insulin staining was in fact lost when ES cells were cultured in insulin-deficient media, and direct evidence for insulin uptake was provided by using fluorescently conjugated insulin in the medium. Thus, insulin immunoreactivity is insufficient evidence for beta cell differentiation.

\section{References}

1. Differentiation of embryonic stem cells to insulin-secreting structures similar to pancreatic islets.

2. Science, [http://www.sciencemag.org] 